\title{
Pliocene agglutinated benthic Foraminifera from Site U1341 in the Bering Sea (IODP Expedition 323)
}

\author{
Michael A. KAMINSKI ${ }^{1,2, *}$, Sev KENDER ${ }^{3}$, Agnieszka CIUREJ ${ }^{4}$, \\ Ramona BĂLC ${ }^{5}$ and Eiichi SETOYAMA ${ }^{1}$ \\ 1 Earth Sciences Department, King Fahd University of Petroleum and Minerals, PO Box 701, Dhahran, 21361, Saudi Arabia \\ 2 Department of Earth Sciences, UCL, Gower Street, London, WC1E 6BT, United Kingdom \\ 3 British Geological Survey, Keyworth, Nottingham, NG12 5GG, United Kingdom \\ 4 Institute of Geological Sciences, Polish Academy of Sciences, Senacka 1, 31-002 Kraków, Poland \\ 5 Faculty of Environmental Science, Babeş-Bolyai University, Fântânele 30, 400294, Cluj-Napoca, Romania
}

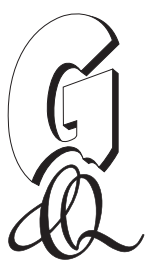

Kaminski M.A., Kender S., Ciurej A., Bălc R. and Setoyama E. (2013) Pliocene agglutinated benthic Foraminifera from Site U1341 in the Bering Sea (IODP Expedition 323). Geological Quarterly, 57 (2): 335-342, doi: 10.7306/gq.1087

\begin{abstract}
We present the first record of benthic foraminiferal assemblages from 92 samples collected at approx. $3 \mathrm{~m}$ resolution in the bottom part of Hole U1341B drilled in the southern Bering Sea during Integrated Ocean Drilling Program (IODP) Expedition 323. Pliocene agglutinated foraminiferal are generally rare within highly diatomaceous claystones occurring from the base of the hole at $601.87 \mathrm{~m}$ below sea floor (mbsf) to $~ 320 \mathrm{mbfs}$. The agglutinated foraminiferal assemblages are strongly dominated by the infaunal genera Eggerella, Karreriella, Martinotiella, and Spirosigmoilina. The calcareous-cemented Eggerella and Martinottiella are canaliculated with pores that are open to the test surface. Tubular agglutinated foraminifera are rare and are only found in isolated samples. The ecological information gained from this assemblage supports other proxy information indicating high levels of organic productivity and severely hypoxic conditions in the Bering Sea deep water during the Pliocene.
\end{abstract}

Key words: Benthic Foraminifera, Pliocene, taxonomy, Bering Sea, hypoxia.

\section{INTRODUCTION}

The Bering Sea is the third largest marginal sea in the world surpassed only by the Mediterranean and South China seas (Hood, 1983). The northern half of the Bering Sea consists of a shallow $(0-200 \mathrm{~m})$ neritic environment that is covered seasonally by sea ice whereas the southern half is a much deeper silled basinal setting, with little seasonal ice. IODP Expedition 323 drilled two sites on the Bowers Ridge in the southwestern part of the Bering Sea, an extinct arc system that extends 300 $\mathrm{km}$ north from the Aleutian Island arc (Fig. 1). Drilling at Site U1341 located at a water depth of $2,177 \mathrm{~m}$ recovered nearly $600 \mathrm{~m}$ of diatomaceous sediment, and provides a geological record of past intermediate water conditions in the Bering Sea. The site is located just below the modern oxygen minimum zone (OMZ), which causes the occasional formation of laminated sediments. Fluctuations in the intensity or depth of the

\footnotetext{
* Corresponding author, e-mail: kaminski@kfupm.edu.sa Received: March 8, 2013; accepted: April 3, 2013; first published online: April 12, 2013
}

$\mathrm{OMZ}$ on a variety of timescales should be reflected by benthic foraminiferal records at this site and can be compared to shallower sites (Takahashi et al., 2005).

The primary objective of drilling at Site U1341 was to study high-resolution "Pliocene-Pleistocene" palaeoceanography in the southern part of the Bering Sea at a western flank location of Bowers Ridge. Previous DSDP coring (at Site 188) and subsequent piston core studies in the region documented high sedimentation rates of $>100 \mathrm{~m} / \mathrm{my}$ and the presence of appropriate microfossils for palaeoceanographic studies (Takahashi et al., 2005). The age model for Hole $1341 \mathrm{~B}$ is constrained by the presence of stratigraphically important diatoms, silicoflagellates, and ebridians (Expedition 323 scientists, 2009). The interval considered in this study is assigned a Pliocene age based on the last occurrence of the ebridian Ebriopsis antiqua antiqua in Cores U1341B-37H, and the last occurrence datum of the silicoflagellate Distephanus jimlingii in Cores U1341B-38H, indicting the whole of the studied interval is older than ca. 2.47 Ma. The base of the cored interval in Hole 1314B is assigned to the lower Pliocene based on the last occurrence of the radiolarian Dictyophimus bullatus (3.8-4.0 Ma) in Core U1341B71X.

The purpose of this paper is to report the taxonomy and biostratigraphy of the Pliocene agglutinated foraminifera from 


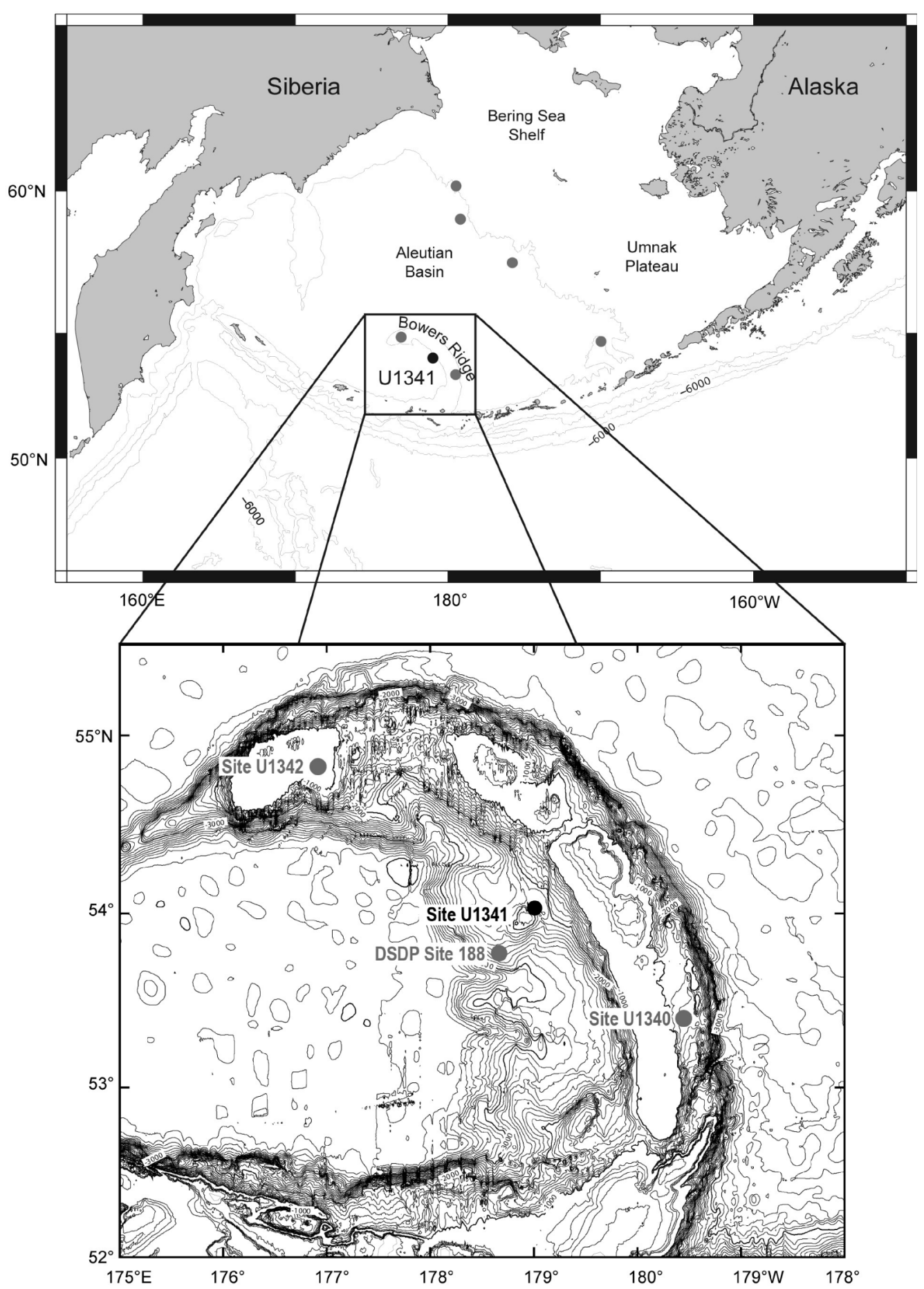

Fig. 1. Location of Site U1341 and other IODP sites (grey dots) near Bowers Ridge, southern Bering Sea

this highly productive part of the northern Pacific Ocean. The ultimate goal is to establish benthic foraminiferal records from IODP holes in the Bering Sea at a range of timescales, for use as proxies of oxygenation and productivity.

\section{MATERIAL AND METHODS}

IODP Expedition 323 successfully drilled seven sites whose sediments capture the spatial and temporal evolution of the Be- ring Sea through the Pliocene and Pleistocene. This study focuses on the oldest stratigraphic record recovered during IODP Expedition 323. The cores recovered on IODP Expedition 323 constitute the only continuously-cored high-latitude record of "Pliocene-Pleistocene" biotic and climatic change available for study in the northern Pacific recovered thus far by the Ocean Drilling Program. Samples (approx. $20 \mathrm{~cm}^{3}$ ) were collected from the working halves of Site U1341B cores during the postcruise sampling meeting using a metal spatula. Samples were gently sieved over a $63 \mu \mathrm{m}$ screen, using just a water spray. Sample 
residues were then air-dried and benthic foraminifera were picked into cardboard microslides using a fine brush. Specimens were imaged using a JSM-5900LV SEM at KFUPM in Dhahran.

\section{RESULTS}

Agglutinated foraminifera were found to be a minor component in the richly diatomaceous claystones recovered in Hole $\mathrm{U} 1341 \mathrm{~B}$, and some samples were barren of foraminifera. The majority of samples examined are noncalcareous and contain only a few specimens of agglutinated foraminifera. The samples from Core U1341B-71X (the base of the hole) until the lower part of Core U1341B, 63X contain only agglutinated foraminifera. Calcareous benthic foraminifera were found in isolated samples in the upper part of the studied section. These are generally less abundant than the agglutinated species, mostly consist of nodosariids, buliminids, Uvigerina and Melonis, and will be described separately. Planktonic foraminifera, consisting of rare Neogloboquadrina and Globigerina were only found in three samples in the studied interval (U1341B, 61X-5, $115-117 \mathrm{~cm} ; 61 \mathrm{X}, \mathrm{CC} ; 47 \mathrm{H}, \mathrm{CC})$

The abundance of agglutinated foraminifera in the noncalcareous sediments varies from 0 to 224 specimens per sample. A total of nine species were found in the studied interval: these are (in descending order of abundance), Martinottiella sp. 1, Eggerella sp. 1, Karreriella sp. 1, Spirosigmoilinella compressa Matsunaga, Psammosiphonella sp., Eggerella bradyi (Cushman), Martinottiella sp. 2, Rhabdamminella sp. and Bathysiphon sp. 1 (Figs. 2-4). The abundances of individual species are given in Appendix $1^{*}$. Because the common species of agglutinated foraminifera extend through the whole Pliocene interval in Hole U1341B, the interval is not further subdivided.

\section{SYSTEMATIC PALAEONTOLOGY}

Taxonomic identifications are based largely on the published monographs of Miocene foraminifera, including Cicha et al. (1998), van Morkhoven et al. (1986), and Kender et al. (2008). The systematic classification of the agglutinated foraminifera follows Kaminski (2004).

\section{Genus Bathysiphon Sars, 1872 \\ Bathysiphon sp. 1 \\ (Fig. 2Ca, Cb)}

D e s c r i p t i o n. - Test a straight unbranched elongate tube, open at both ends, nonseptate. Wall agglutinated, thick, of silt-sized grains with clay particles, several grains thick, with very smooth inner and outer surfaces, without sponge spicules. Aperture at the open end of the tube.

$\mathrm{R}$ e $\mathrm{m}$ a r k s. - This species differs from the type species of Bathysiphon in lacking any obvious biogenic siliceous particles such as sponge spicules embedded within the wall. Instead, the wall is comprised of particles of fine silt and clay. The test has a brownish colour, likely resulting from the presence of clay particles. Very rare in Hole U1341B.

\section{Genus Rhabdamminella de Folin, 1887 Rhabdamminella sp.}

$$
\text { (Fig. 2B) }
$$

D e s c ription. - A robust tube with abundant sponge spicules oriented parallel to the long axis of the test.

$\mathrm{R}$ e $\mathrm{m}$ a r k s. - Only found in a single sample (U1341B70X-5, 146-148 cm).

Genus Psammosiphonella Avnimelich, 1952 Psammosiphonella cf. cylindrica (Glaessner) (Fig. 2A, D)

cf. Rhabdammina cylindrica Glaessner, 1937, p. 354, pl. 1, fig.1.

D e s c r i p t i o n. - Test tubular, monothalamous, round in cross section, straight, of even diameter or slightly tapering in one direction without any distinct swelling or "centre of organisation". The inner surface of the tube is even, not constricted. Wall thick, composed of equidimensional mineral grains, mostly quartz, cemented with organic material.

R e marks. - This species most closely resembles Psammosiphonella cylindrica (Glaessner), which is known from Paleogene and Upper Cretaceous flysch-type deposits in Europe (Kaminski and Gradstein, 2005), differing only in its larger dimensions. Rare in Hole U1341B.

Genus Spirosigmoilinella Matsunaga, 1955 Spirosigmoilinella compressa Matsunaga, 1955

$$
\text { (Fig. 2E-G) }
$$

Spirosigmoilinella compressa n.sp. - Matsunaga, 1955, p. 50, figs. 1, 2 Spirosigmoilinella compressa Matsunaga, 1955 - Kaminski and Gradstein, 2005, p. 218, text-fig. 36, pl. 36, figs. 1-7.

De s cription. - Chambers nearly planispirally enrolled, two per whorl, plane of coiling in early stage changing slightly to show a sigmoid curve in cross section, later with coiling in a single plane. Wall finely agglutinated, grey in colour. Aperture rounded, at the end of a short neck without a tooth.

$\mathrm{R}$ e $\mathrm{m}$ a r k s. - This species is characterized by initial portion that is coiled in a sigmoidal curve. Kaminski and Gradstein (2005) discussed the synonymy of the type species. The species is known from the Miocene of the Japan Sea and Sakhalin Island. The species is restricted to the Miocene in the Sea of Japan (Hanagata et al., 2001). This the first report of the species in sediments of Early Pliocene age.

\section{Genus Eggerella Cushman, 1935 Eggerella bradyi (Cushman)}

$$
\text { (Fig. 2l) }
$$

Verneuilina bradyi n.sp. - Cushman, 1911, p. 54, text-figs. 87a, b. Eggerella bradyi (Cushman) - Cushman, 1933, p. 33, pl. 4, fig. 1. Eggerella bradyi (Cushman) - Cushman, 1937, p. 52, pl. 5, fig. 19 Eggerella bradyi (Cushman) - Szarek, 2001, p. 93, pl. 8, figs. 3, 4 (with synonyms).

$\mathrm{R}$ e $\mathrm{m}$ a r k s. - This is a widely distributed species that is known from the Arctic (Cushman, 1937). Szarek (2001) reported the species from uppermost bathyal to lower bathyal depths in the western Pacific (Sunda and Vietnamese shelves). In the studied interval it is found only in sample U1341B-61X-5, $115-117 \mathrm{~cm}$, in association with calcareous benthic foraminifera. 


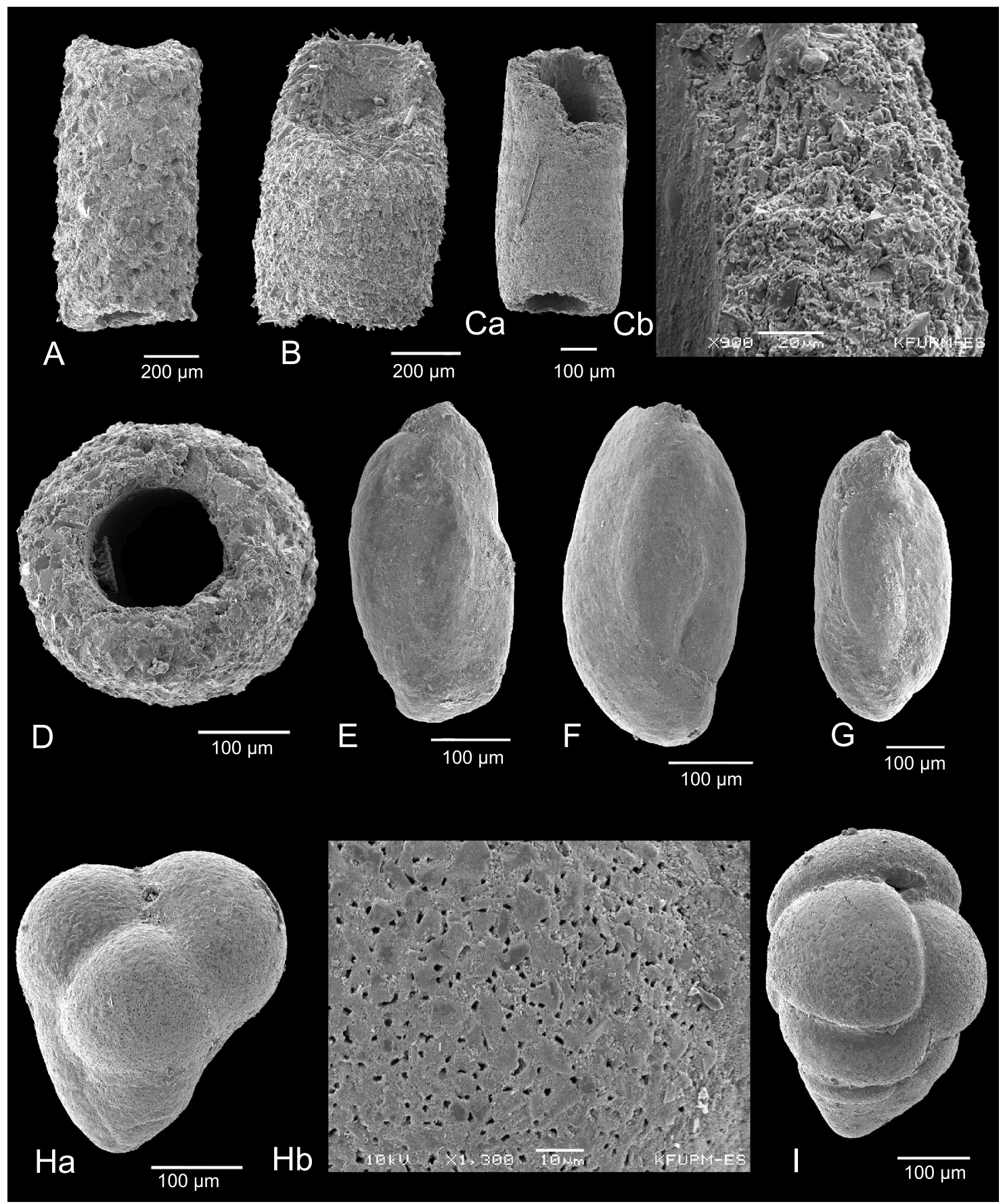

Fig. 2A - Psammosiphonella cf. cylindrica (Glaessner), U1341B-70X-5, 146-148 cm; B - Rhabdamminella sp. U1341B-70X-5, 146-148 cm; Ca - Bathysiphon sp. U1341B-70X, CC; Cb-detail of wall; D - Psammosiphonella cf. cylindrica (Glaessner), U1341B-70X, CC, top view; E-G - Spirosigmoilinella compressa Matsunaga; E U1341B-61X-3, 146-148 cm; F - U1341B-53H, CC; G - U1341B-61X-3, 146-148 cm; Ha - Eggerella sp. 1. U1341B-63X-3, 146-148 cm; Hb - detail of wall showing open pores; I - Eggerella bradyi (Cushman), U1341B-61X-5, 115-117 cm

\section{Eggerella sp. 1 (Fig. 2Ha, $\mathrm{Hb}$ )}

D e s c r i p t i o n. - Test small, subconical, early stage in trochospiral coil of five inflated chambers per whorl, at least in the microspheric generation, quickly reducing to three chambers per whorl. Wall finely agglutinated, with much calcareous cement, coarsely canaliculate, the pores with an organic lining.
Aperture a round to oval opening near the base of the apertural face, produced, and bordered by a narrow lip.

$\mathrm{R}$ e $\mathrm{m}$ a r k s. - This species differs from the type species Eggerella bradyi (Cushman) in its smaller dimensions and in possessing an aperture that is more rounded and produced. Additionally, specimens investigated in the SEM are observed to have canaliculae that are open to the test surface in the lower part of the chamber wall (Fig. 2Ha). The specimens do not ap- 


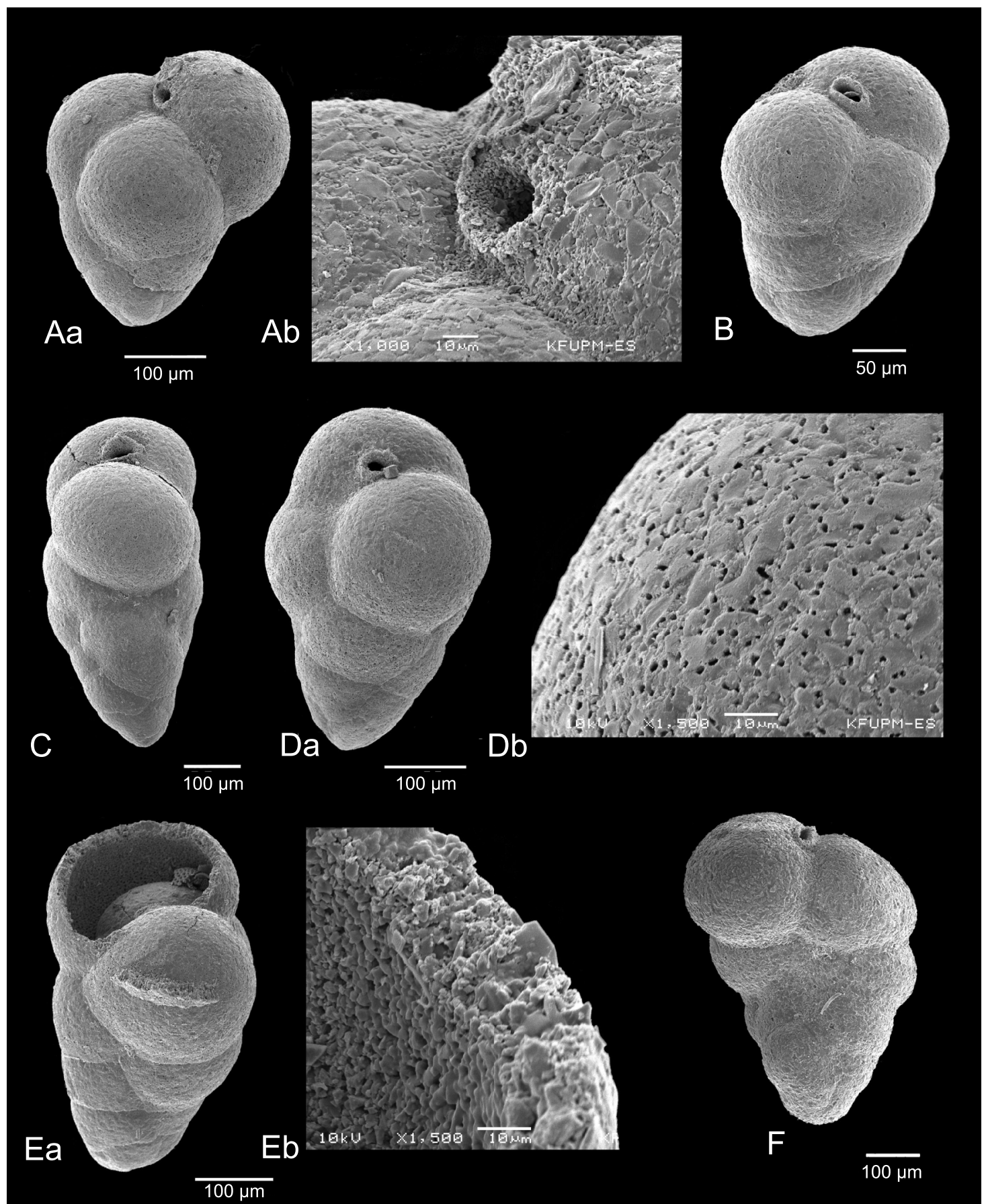

Fig. 3Aa-F - Karreriella sp.1; Aa - juvenile individual showing open canaliculae on the bottom half of the chambers, U1341B-70X, CC; Ab - detail of aperture showing finely agglutinated lip and terrazzo surface of agglutinated grains; B - larger specimen with aperture becoming oval, U1341B-70X, CC; C - specimen with a pair of biserial chambers, U1341B-52H-2, 130-132 cm; Da - specimen becoming biserial, U1341B-53H, CC; Db - detail of wall showing evenly-spaced open canaliculae, some of which are surrounded by a rim of agglutinated grains; Ea - broken specimen, U1341B-53H, CC; Eb - detail of wall; F - larger specimen with two pairs of biserial chambers, U1341B-61X-5, 115-117 cm

pear to be abraded, so this feature appears to be primary. In the type species $E$. bradyi the test surface appears to be smoothly finished, and canaliculae are closed at the surface by a thin imperforate layer of agglutinated grains. This species, by possessing open canaliculae in the outer wall of the test (but not in the intercameral septa), has apparently developed a physiological response to survive the low-oxygen conditions present in the deep Bering Sea.

\section{Genus Karreriella Cushman, 1933 Karreriella sp. 1}

$$
\text { (Fig. 3A-F) }
$$

D e s c ription. - Test free, elongate, initially trochospiral with up to five chambers per whorl, later reduced to twisted triserial and finally becoming biserial in just the final one or two pairs of chambers. Chambers in the terminal biserial part 


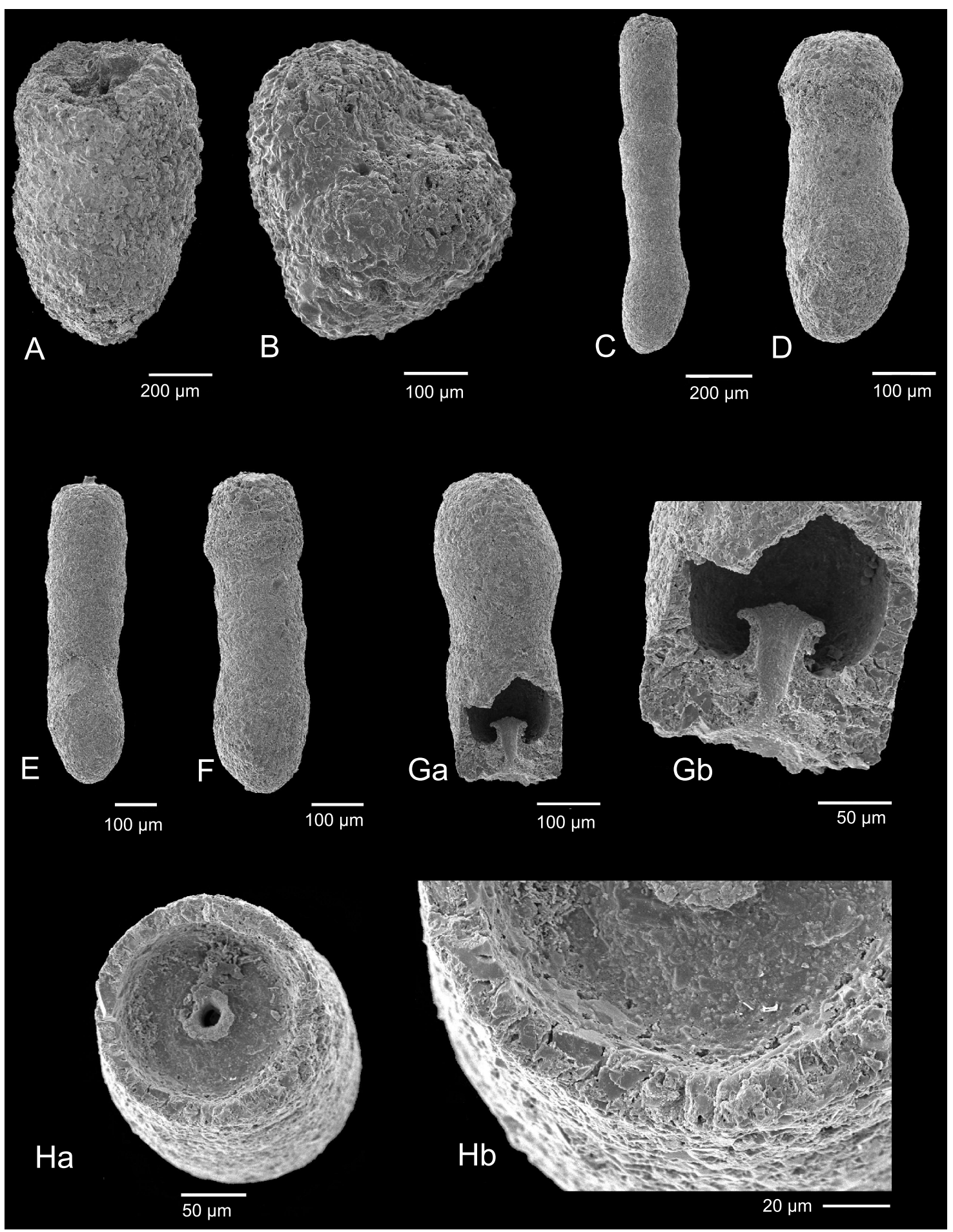

Fig. 4A, B - Martinottiella sp. 2. U1341B-63X-3, 146-148 cm: A - adult specimen, B - juvenile individual; C-Hb Martinottiella sp. 1. U1341B-70X, CC; C-G - lateral views of adult and juvenile specimens; Ga, Gb - broken specimen showing details of aperture and sinuous pseudopores; $\mathrm{Ha}, \mathrm{Hb}$ - top view of a broken uniserial fragment, showing details of the wall structure

are globular, with depressed sutures. Wall finely agglutinated, with calcareous cement, canaliculated, a smooth outer surface, with pseudopores open to the surface. Aperture areal, a rounded opening slightly above the base of the apertural face in the triserial stage, becoming more areal and increasingly oval in the biserial adult stage, produced, and surrounded by a distinct lip.
R e m a rks. - This species can be distinguished from Eggerella sp. 1 in possessing a terminal biserial stage with an oval aperture. The species bears some resemblance to Meidamonella novangliae (= Gaudryina baccata var. novangliae Cushman, 1922), but differs in possessing a much reduced biserial part and an oval (rather than slit-like) aperture. The ag- 
glutinated wall is several grains thick, with a terrazzo outer surface (consisting of grains in the 5-10 $\mu \mathrm{m}$ size range the flat sides oriented normal to the test surface). Grains are surrounded by canaliculae several $\mu \mathrm{m}$ in diameter that are open at the test surface. At higher magnification some of the openings appear to be surrounded by elevated rims of fine agglutinated grains.

\section{Genus Martinottiella Cushman, 1933 Martinottiella sp. 1 (Fig. 4C-H)}

Martinottiella communis (d'Orbigny). - Szarek, 2001, p. 93, pl. 8, fig. 10 (cf. fig. 9) Martinottiella communis (d'Orbigny). - Hanagata, 2006, pl. 2, figs. 5, 6 .

D e s c r i p t i o n. - Test free, elongate, cylindrical, early trochospiral coil with four to five chambers per whorl, later reduced to triserial, biserial, and a relatively long final uniserial stage. Wall finely agglutinated, canaliculate, with an inner organic lining. Aperture terminal, round, produced on a short tubular neck in the center of the flattened terminal face.

$\mathrm{R}$ e $\mathrm{m}$ a r k s. - This species differs from the type species Martinottiella communis from the (Badenian) of the Vienna Basin in its much smaller dimensions (the type specimens from Baden illustrated by Papp and Schmidt, 1985, are over $2 \mathrm{~mm}$ in length) and thin finely agglutinated wall that possesses coarse, meandering pseudopores (Fig. 4Gb). The wall is grey in colour, but at high magnification has a "salt and pepper" appearance owing to the presence of some mafic grains. Additionally, the aperture is round and produced, rather than in the form of an oval or crescentic slit (see Papp and Schmidt, 1985: pl. 66, figs. 6-8). Our specimens correspond well to one of the specimens from the western Pacific illustrated by Szarek (2001: pl. 8, fig. 10) as Martinottiella communis. Similar small $(<300 \mu \mathrm{m})$ smooth-walled specimens of this species were illustrated by Hanagata (2006) from upper Miocene dysoxic sediments in northern Japan. This species is likely the one reported by Echols (1973) as Martinottiella communis from the Upper Miocene and Lower Pliocene of DSDP Leg 19 sites in the Bering Sea. This species has been recorded from within low oxygen intermediate waters off the Pacific coast of Japan (Kaiho and Hasegawa, 1986), where oxygen levels are somewhat higher than in the modern Bering Sea bottom water.

\section{Martinottiella sp. 2 \\ (Fig. 4A, B)}

D e s c r i p t i o n. - Test free, elongate, cylindrical, early trochospiral coil with four to five chambers per whorl, later reduced to triserial, biserial, and a short uniserial stage. Wall coarsely agglutinated, thick, canaliculate, with an inner organic lining. Aperture terminal, round, produced on a short tubular neck in the center of the flattened terminal face.

$\mathrm{R}$ e $\mathrm{m}$ a $\mathrm{rk} \mathrm{s}$. - Differs from Martinottiella sp. 1 in its larger dimensions and in possessing a thick agglutinated wall. It has a very short uniserial stage. Very rare.

\section{DISCUSSION}

The Bering Sea region is one of the most highly biological productive regions in the world (Sambrotto et al., 1984), and has only limited deep marine connections with the North Pacific. Consequently the oxygen minimum zone extends to deeper levels in the Bering Sea than in the open ocean. The studied location at 2,177 m depth on Bowers Ridge is currently affected by the lower portion of the OMZ, where modern-day oxygen values are below $1.5 \mathrm{ml} / \mathrm{l}$ (Expedition 323 Scientists, 2009). The site is therefore sensitive to changes in the depth of the OMZ that would be caused by heightened productivity and/or reduced ventilation of the bottom waters. The sediment record of the southern Bering Sea includes intervals of laminated diatomaceous sediment that were deposited when conditions became anoxic.

The agglutinated foraminiferal assemblage in the Pliocene of Hole U1341B is dominated by infaunal tapered elongated forms that would be best placed within Morphotype $4 \mathrm{~b}$ of Kaminski and Gradstein (2005). This morphotype is known to be the dominant one in hypoxic conditions such as in the modern California Borderlands Basins (Kaminski et al., 1995), under the OMZ off West Africa (Kender et al., 2008a, b; 2009), or in association with Upper Cretaceous dysoxic shales (Bak, 2006; Cetean et al., 2008). The dominant species (Martinotiella $\mathrm{sp} .1$ ) has been identified as Martinotiella communis (d'Orbigny) in previous studies of "Miocene-Pliocene" foraminiferal assemblages in NW Pacific region (Echols, 1971; Szarek, 2001; Hanagata, 2006), but its true taxonomic affinity to the much larger and coarsely-agglutinated "Mediterranean-Paratethyan" species remains to be determined. Hanagata (2006) reported an assemblage dominated by " $M$. communis" [=Martinottiella sp. 1] with rare Spirosigmoilinella compressa in the upper Miocene-Pliocene of the northern Japan Sea, and concluded that the dominance of Martinottiella was related to "high levels of organic matter flux, which were present in the late Miocene-Pliocene".

The agglutinated foraminifera recovered from Hole U1341B display additional morphological features that can be associated with hypoxic environments: these include small test size and a thin wall, and the presence of a highly perforate test (Bernhard, 1986). In the case of agglutinated taxa, perforations are in the form of canaliculae that are normally closed at the surface by a thin imperforate layer of agglutinated grains. In the case of two of the investigated species, the canaliculae are open at the test surface. The test surface does not appear to be damaged by abrasion or dissolution, which leads to the conclusion that this is a primary feature. Although open canaliculae have been observed previously (Mikhalevich, 2011), our finding is the clearest example of such a feature that has been described thus far in an agglutinated foraminifer. Such a feature in an agglutinated species recalls the perforate wall structure of a calcareous benthic foraminifer, and is likely to be an adaptation for survival in severely hypoxic conditions.

\section{CONCLUSIONS}

Nine species of agglutinated foraminifera were found in the Pliocene of Hole 1341B in the southern Bering Sea. The recovered assemblage displays low abundance and diversity, and consists mainly of infaunal taxa dominated by a species Martinottiella. The assemblage strongly resembles the "Martinottiella communis assemblage" of the northern Japan Sea described by Hanagata (2006). Two of the taxa assigned to Eggerella and Karreriella display a porous wall texture with canaliculae that are open to the surface of the test, which is likely an adaptation to the severely hypoxic conditions present in the deep Bering Sea during the Pliocene. 
Acknowledgements. We thank Prof. K. Takahashi for the opportunity to participate in the Expedition 323 scientific party. This study was sponsored by a Fast-Track Grant (SB1010001) from the Deanship of Scientific Research, King Fahd University of Petroleum \& Minerals. SK publishes with permission of the
Executive Director of the British Geological Survey (NERC). The journal reviewers S. Filipescu, M. Gonera and D. Peryt are kindly acknowledged for their helpful comments. This is contribution nr. 100 of the Deep-Water Benthic Foraminiferal Project.

\section{REFERENCES}

Bak K. (2006) Sedimentological, geochemical and microfaunal responses to environmental changes around the CenomanianTuronian boundary in the Outer Carpathian Basin; a record from the Subsilesian Nappe, Poland. Palaeogeography, Palaeoclimatology, Palaeoecology, 237: 335-358.

Bernhard J.M. (1986) Characteristic assemblages and morphologies of benthic foraminifera from anoxic, organic-rich deposits: Jurassic through Holocene. Journal of Foraminiferal Research, 16: 207-215.

Cetean C.G., Bălc R., Kaminski M.A., Filipescu S. (2008) Preliminary Observations on the biostratigraphy of the CenomanianTuronian boundary in the Eastern Carpathians (Dâmbovița Valley): preliminary observations. Studia Universitatis BabesBolyai, Geologia, 53 (1): 11-23.

Cicha I., Rögl F., Rupp C., Ctyroka J., eds. (1998) Oligocene-Miocene foraminifera of the Central Paratethys. Abhandlungen der Senckenbergischen Naturforschenden Gesellschaft, 549.

Cushman J.A. (1911) A monograph on the foraminifera of the North Pacific Ocean; Part II - Textulariidae. United States National Museum Bulletin, 71.

Cushman J.A. (1922) The foraminifera of the Atlantic Ocean, Part. 3. Textulariidae. Bulletin of the United States National Museum, 104 (3): 1-143.

Cushman J.A. (1933) Some new foraminiferal genera. Contributions from the Cushman Laboratory for Foraminiferal Research, 9: 32-38.

Cushman J.A. (1937) A monograph of the foraminiferal family Valvulinidae. Cushman Laboratory for Foraminiferal Research Special Publication, 8: 1-210.

Echols R.J. (1973) Foraminifera, Leg 19, Deep Sea Drilling Project. Initial Reports of the Deep Sea Drilling Project, 19: 721-735.

Glaessner M.F. (1937) Studien über Foraminiferen aus der Kreide und dem Tertiär des Kaukasus; 1. Die Foraminiferen der ältesten Tertiärschichten des Nordwest-Kaukasus. Problems of Paleontology, 2-3: 349-408. Moscow.

Expedition 323 Scientists (2009) IODP Preliminary Reports, 323. doi:10.2204/iodp.pr.323.2009

Hanagata S. (2006) Foraminiferal proxies of dissolved oxygen and their changes across the Miocene/Pliocene boundary in the Japan Sea. Stratigraphy, 3: 285-306.

Hanagata S., Motoyama I., Miwa M. (2001) Geologic ages of the last occurrence of Spirosigmoilinella compressa and the first occurrence of Miliammina echigoensis (benthic foraminifera), and their paleoceanographic implications - response to the latest Miocene-earliest Pliocene sea level changes. Journal of the Geological Society of Japan, 107 (2): 101-116.

Hood D.W. (1983). The Bering Sea. In: Estuaries and Enclosed Seas (ed. B.H. Ketchum): 337-373. Elsevier.

Kaiho K., Hasegawa S. (1986) Bathymetric distribution of benthic foraminifera in the bottom sediments off Onohama, Fukushima
Prefecture, northeast Japan. In: Studies on Cenozoic Benthic Foraminifera in Japan (eds. Y. Matoba and M. Kato): 43-52. Akita (Akita University).

Kaminski M.A. (2004) The Year 2000 classification of agglutinated foraminifera. Grzybowski Foundation Special Publication, 8: 237-255.

Kaminski M.A., Gradstein F.M. (2005) Cenozoic cosmopolitan deep-water agglutinated foraminifera. Grzybowski Foundation Special Publication, 10

Kaminski M.A., Boersma A., Tyszka J., Holbourn A.E.L. (1995) Response of deep-water agglutinated foraminifera to dysoxic conditions in the California borderland basins. Grzybowski Foundation Special Publication, 3: 131-140.

Kender S., Kaminski M.A., Jones R.W. (2008a) Oligocene deepwater agglutinated foraminifera from the Congo Fan, Offshore Angola: Palaeoenvironments and assemblage distributions. Grzybowski Foundation Special Publication, 13: 107-156.

Kender S., Kaminski M.A., Jones R.W. (2008b) Early to Middle Miocene Foraminifera from the deep-sea Congo Fan, Offshore Angola. Micropaleontology, 54: 477-568.

Kender S., Peck V.L., Jones R.W., Kaminski M.A. (2009) Middle Miocene oxygen minimum zone expansion offshore West Africa: Evidence for global cooling precursor events. Geology, 37: 699-702

Matsunaga T. (1955) Spirosigmoilinella, a new foraminiferal genus from the Miocene of Japan. Transactions and Proceedings of the Paleontological Society of Japan, n. ser., 18: 49-50.

Mikhalevich V. (2011) Wall structure of some Antarctic foraminiferal genera. Grzybowski Foundation Special Publication, 16: 115-129.

Papp A., Schmid M.E. (1985) The fossil Foraminifera of the Tertiary Basin of Vienna: revision of the monograph by Alcide d'Orbigny (1846). Abhandlungen der geologischen Bundesanstalt, 37: $1-311$

Sambrotto R.N., Goering J.J., McRoy C.P. (1984). Large yearly production of phytoplankton in the western Bering Strait. Science, 225: 1147-1150.

Szarek R. (2001) Biodiversity and biogeography of recent benthic foraminiferal assemblages in the south-western South China Sea (Sunda Shelf). Ph.D. thesis, Christian-Albrechts Universität zu Kiel.

Takahashi K., Jordan R.W., Boltovskoy D. (2005) Paleoceanography of the Bering Sea and adjacent areas - a preface. Deep Sea Research II, 52: 16-18.

Van Morkhoven F.P.C.M., Berggren W.A., Edwards A.S. (1986) Cenozoic cosmopolitan deep-water benthic foraminifera. Bulletin des Centres de Recherches Exploration Elf-Aquitaine, 11: $1-421$ 